\title{
Building Theory at the Intersection of Ecological Sustainability and Strategic Management
}

\author{
Helen Borland • Véronique Ambrosini • \\ Adam Lindgreen · Joëlle Vanhamme
}

Received: 10 November 2014/Accepted: 12 November 2014/Published online: 27 November 2014

(C) Springer Science+Business Media Dordrecht 2014

\begin{abstract}
This article builds theory at the intersection of ecological sustainability and strategic management literature-specifically, in relation to dynamic capabilities literature. By combining industrial organization economicsbased, resource-based, and dynamic capability-based views, it is possible to develop a better understanding of the strategies that businesses may follow, depending on their managers' assumptions about ecological sustainability. To develop innovative strategies for ecological sustainability, the dynamic capabilities framework needs to be extended. In particular, the sensing-seizing-maintaining competitiveness framework should operate not only within the boundaries of a business ecosystem but in relation to global biophysical ecosystems; in addition, two more dynamic capabilities should be added, namely, remapping and reaping. This framework can explicate core managerial beliefs about ecological sustainability. Finally, this
\end{abstract}

\footnotetext{
H. Borland

Aston Business School, Aston University, Aston Triangle, Birmingham BE 7ET, UK

e-mail: h.m.borland@aston.ac.uk

V. Ambrosini

Department of Management, Monash University, 900

Dandenong Road, Caulfield East, VIC 3145, Australia

e-mail: v.ambrosini@monash.edu

\author{
A. Lindgreen $(\square)$ \\ Cardiff University, Aberconway Building, Colum Drive, \\ Cardiff CF10 3EU, UK \\ e-mail: lindgreena@cardiff.ac.uk \\ J. Vanhamme \\ Edhec Business School, 24 avenue Gustave Delory, CS 50411, \\ 59057 Roubaix Cedex, France \\ e-mail: joelle.vanhamme@edhec.edu
}

Department of Marketing and Strategy, Cardiff Business School,
}

approach offers opportunities for managers and academics to identify, categorize, and exploit business strategies for ecological sustainability.

Keywords Dynamic capabilities - Ecocentrism · Ecological sustainability · Transformational business strategy

\section{Introduction}

We set out to examine dynamic capabilities literature from the perspective of ecological sustainability and ecocentrism. Borland and Lindgreen (2013), Gladwin et al. (1995), Iyer (1999), and Purser et al. (1995) have started examining marketing and management aspects from an ecocentric perspective, yet the field remains underresearched, with a dearth of investigations of strategy and, in particular, the dynamic capabilities view of the firm using anything but a conventional, anthropocentric perspective (Castiaux 2012; Wu et al. 2012). A dynamic capabilities view-which primarily addresses how firms renew and refresh their valuable resources and capabilities in changing environments to maintain their competitive advantage by engaging in sensing, seizing, and reconfiguring activities (Teece 2007; Teece et al. 1997)—also might inform perspectives on ecocentrism and ecological sustainability. On the basis of our theoretical investigation, we propose a framework to articulate a set of five corporate ecocentric transformational strategies, which we call the 5Rs: rethink, reinvent, redesign, redirect, and recover. The 5Rs framework maps directly onto five ecocentric dynamic capabilities, three that we take from Teece (2007) and two new ones: sensing, seizing, reconfiguring, remapping, and reaping. We thus contribute to dynamic capabilities literature by elaborating 
how its central framework can be expanded to apply to firms that exhibit a primary concern with ecological sustainability.

In recent years, sustainability has become a far more salient issue for organizations and academics alike (Dahlmann and Brammer 2011; Elkington 2012; Hahn et al. 2014; Lindgreen and Swaen 2010; Metcalf and Benn 2013; Wittneben et al. 2012). In traditional, anthropocentric, management literature, multiple studies now investigate how companies implement environmental management processes in response to increasing pressures to meet environmental management standards or regulations (e.g., González-Benito and González-Benito 2005; Schaefer 2007; Westley and Vredenburg 1996), as well as whether being environmentally proactive is a source of competitive advantage (e.g., Aragón-Correa and Sharma 2003; Esty and Charnovitz 2012; Hart 1995; Orlitzky et al. 2003). For example, Hart (1997) expands the conversation about sustainability, to extend beyond just limiting the negative impact of firms and includes their potentially positive impact; Stead and Stead (2010) sketch the evolution from traditional management to sustainable strategic management. However, little work details how assumptions about ecological sustainability influence strategic orientations; a particular gap remains in terms of theorizing about this aspect of sustainability. To take extant literature further, we seek-borrowing Zahra and Newey's (2009) terms-to build theory at the intersection.

With an interdisciplinary approach, we concentrate on ecological sustainability rooted in different scientific disciplines (Borland 2009) and examine strategic management perspectives in light of this diverse literature. In turn, we argue that industrial organization economics-based strategic management approaches (Porter 1980, 1985), the resource-based view (RBV; Barney 1991; Hart 1995; Levitas and Ndofor 2006), and the dynamic capabilities view of the firm (Augier and Teece 2008; Teece 2007) provide a theoretical grounding to understand the extent of businesses' involvement in the pursuit of ecological sustainability. The boundaries of the dynamic capabilities framework thus may need extending: We suggest that the ecosystem framework of dynamic capabilities (Teece 2007) should include not only the business environment but also the natural environment. To contribute to extant literature, we thus build on the theoretical foundation of sustainability, positioning it within strategic management literature.

We begin by outlining our theoretical background. First, we define both sustainability and ecological sustainability and highlight the two main philosophical assumptions about ecological sustainability in the Western world, namely, the anthropocentric and ecocentric. Second, we continue our theoretical development by explaining the need to build theory by integrating ecological sustainability and strategic management literature, which reveals valuable insights into strategy literature. Third, at this intersection, we apply our theoretical review of extant literature by illustrating business strategies based on anthropocentric principles, as well as business strategies that integrate ecological sustainability into their core strategic activity, which we refer to as transitional and transformational strategies. Fourth, to substantiate our theoretical argument, we present a firm that has transitioned from an anthropocentric to an ecocentric approach, which reflects our argument that though existing dynamic capabilities frameworks are appropriate for developing ecocentric transformational strategies, they can do so only when the boundaries are defined as the global, biophysical ecosystem, not a business ecosystem.

We contribute to dynamic capabilities literature by proposing an extension of the boundaries of its central framework and by adding two new dynamic capabilities, remapping and reaping, which help us close the loop on business activity. This extension of Teece's (2007) framework is relevant to firms that want to deploy dynamic capabilities to achieve ecological sustainable strategies. We also emphasize the importance of managerial mindsets; if managers do not hold ecocentric beliefs, ecocentric transformational strategies are not possible. Thus, in addition to highlighting the intersection of ecological sustainability with dynamic capabilities literature, we start theorizing about ecological concerns, an area that thus far has been relatively atheoretical (Corley and Gioia 2011). We end this article with some managerial implications regarding how managers can start diagnosing the ecological sustainability of their firms' strategies and determining how to transform their current strategies into ecocentric strategies, ecocentric dynamic capabilities, and an ecocentric firm vision of the future.

\section{Defining Sustainability}

The term sustainability often serves as a sort of catch-all phrase to describe an ongoing phenomenon with desirable characteristics that are replicated in the long term, such as a sustainable financial or economic policy or competitive advantage. In this sense, it is a buzzword for both academia and business practice (Kotler 2011; Mitev and Venters 2009). However, the more precise definition of sustainability used in ecological sciences indicates closed-loop systems that can support themselves in perpetuity, without any external support or input except sunlight (Belz and Peattie 2009; Borland 2009; Lovelock 2000; Stead and Stead 2004). We are interested in this latter type of sustainability, which we refer to as ecological sustainability. 
Porritt (2007, p. 33) defines ecological sustainability as "the capacity for continuance into the long-term future, living within the constraints and limits of the biophysical world." Thus ecological sustainability is the goal, endpoint, or desired destination for the human species, as much as for any other species, and it can be explained, defined, and measured scientifically. In contrast, Porritt argues that sustainable development is the process by which we can move toward sustainability. This process is frequently criticized as being ill-defined and difficult to measure. Sustainable development includes social and economic, as well as environmental, elements, but Porritt (2007) considers the first two elements secondary goals, because everything else is conditional on learning to live sustainably within the Earth's systems and limits. He thus asserts that the pursuit of ecological sustainability is not just non-negotiable but preconditional. Although management literature sometimes confuses the distinction between sustainability and sustainable development, Porritt's (2007) definitions provide clarity, helpful for our argument.

In 1987, the UN Commission on Environment and Development (Brundtland Commission) recommended that sustainability should be viewed as "development that meets the needs of present (species) without compromising the ability of future generations to meet their own needs." However, this phrase frequently gets taken out of context, associated exclusively with human development and progress (sustainable development) rather than the development and progress of all species (sustainability), which was the original meaning of the phrase-as indicated by the report title: "Our Common Future." This gap in understanding and interpretation distinguishes definitions of ecological sustainability from those of sustainable development. Ecological sustainability is ecocentric: It puts all species on an equal footing and thereby includes the balance of nature and human development in perpetuity. Sustainable development, in contrast, is anthropocentric: Its primary focus is human development. We return to these points when we describe some of the main philosophical assumptions associated with ecological sustainability.

As a discipline, ecological sustainability derives from ecological science that in turn has its roots in natural science disciplines, including physics, chemistry, and biology (Borland and Lindgreen 2013). In recent decades, ecological science also has developed its own theories, concepts, and paradigms, as represented by the array of available theories and laws, including systems theory, ecosystems theory, the laws of thermodynamics, and Gaia theory (Borland 2009). Collectively, these theories and laws explain the behavior, homeostatic balance, and maintenance of life on Earth (Lovelock 2000; Orr 2004). Belz and Peattie (2009) provide a useful summary that delineates some properties of ecological sustainability, including a holistic and systems-based view, an open-ended time frame, a global perspective that focuses on ecological sustainability rather than economic efficiency, and recognition of the intrinsic value of nature. Ecological sustainability also entails recognition of the finite limits of nature as a source of resources and a sink for wastes, and it distinguishes between unlimited economic growth (an impossibility) and sustainable growth as a qualitative improvement in means and ends (Ekins 2000; Guest 2010). The qualitative improvement in the quality of life for the human and all other species becomes the focus of attention when designing business strategies for ecological sustainability and, as we argue subsequently, for an ecocentric dynamic capabilities framework.

\section{Two Perspectives on Sustainability}

In this section, we briefly explore two worldviews that relate to the physical environment and sustainability: the anthropocentric perspective and the ecocentric perspective. These perspectives differ in their fundamental beliefs about the natural environment, both generally speaking and specifically in reference to the relationship between humans and other species.

\section{Anthropocentric Perspective}

Broadly, an anthropocentric perspective is characterized by the notion of human exemptionalism: Humans, unlike other species, are exempt from the constraints of nature, and the whole of nature exists primarily for human use, with no inherent value of its own. This perspective is manifested as a belief in abundance and progress, unlimited growth, and prosperity, faith in science and technology, a commitment to a laissez-faire economy, limited government planning and intervention, and private property rights. It illustrates the modern, Western worldview, which posits that land not used for economic gain is wasted and that individuals have the right to develop land for economic profit and do with it as they see fit (Kilbourne 1998; Purser et al. 1995).

Purser et al. (1995) note some limits to anthropocentrism. The most worrying aspect is that there seems to be no overall survival plan (Kilbourne 1998; Purser et al. 1995). The consumption rhetoric is a means to an end that lacks an endpoint. From this perspective, economic growth continues unlimited and unchecked until it reaches the complete destruction of the physical environment and natural resource base (Diamond 2006), as the ultimate end result of anthropocentrism (Banerjee 2003; Capra 2004; Du Nann Winter and Koger 2004).

A key tenet of the anthropocentric perspective is the human-nature dualism, reflecting the assumption that 
humans are above other animals in a socially constructed hierarchy (Purser et al. 1995; Schultze and Stabell 2004; Starik and Marcus 2000). This hierarchy allows people to construe humans as morally superior to nonhumans, thus providing a justification for the domination of nature (Purser et al. 1995). The anthropocentric attitude denies that nature has any inherent worth (Gladwin et al. 1995), even though ecosystems and other species are part of the biophysical world and have properties and needs that exist independent of humans.

The anthropocentric perspective also leads human society to embrace a particular set of cultural values, beliefs, and institutions that collectively provide social lenses through which individuals and groups interpret the social world. This perspective is the current dominant social paradigm (DSP) in Western industrial society (Kilbourne 1998). A DSP serves to legitimize and justify existing institutions, thus serving as a mechanism to justify specific social, political, or economic courses of action (Padelford and White 2009).

\section{Ecocentric Perspective}

Ecocentrism is characterized by the belief that ecosystems have inherent worth for maintaining planetary homeostasis and all life. It reflects notions of holism, integration, and synthesis, according to which human cultural systems must function within the safe operating limits dictated by ecosystems. In this perspective, the integrity of ecosystems is paramount; consequently, animals and plants have as much right to exist as humans. There is also an underlying belief in the need for responsibility toward plants, animals, wilderness, and the planet (Dunlap et al. 2000; Purser et al. 1995).

The ecocentric perspective represents a radical departure from the anthropocentric perspective and DSP, in that it is explicitly concerned with emancipating ecosystems from the effects of human mismanagement, overuse, and exploitation. As a means of fostering deeper appreciation and the intrinsic valuation of nature, ecocentrists seek to effect change at the level of human beliefs, values, and ethics (Iyer 1999). Ecocentric values align with movements to reduce excessive human population growth and human overconsumption, preserve wilderness areas, protect the integrity of biotic communities, and restore ecosystems to a healthy state of equilibrium, referred to by Spilhaus (1972) as ecolibrium.

A healthy ecosystem is dynamic but also ecologically sustainable, because member organisms flourish in their respective niches, free from distress. In turn, they have the capacity for self-renewal, self-management, and self-regulation in a self-perpetuating, closed-loop cycle (continual cycling of nutrients and energy) (Borland 2009). Healthy ecosystems do not require constant repair, upkeep, or management by humans. In contrast, unhealthy ecosystems require environmental management, constant doctoring, and engineering. As Rolston (1994) explains, from an ecocentric perspective, the main issue is conserving natural values that do not place the health of ecosystems at risk. This shift in perspective places primary emphasis on the value of ecosystem integrity (Ketola 2008). Human cultural development is encouraged, as long as ecological integrity or ecosystem health is sustainable (Linnenluecke and Griffiths 2010). In this case, the focus is on ecological sustainability, rather than sustainable development or environmental management; it is ecological sustainability that ultimately supports human existence (Bansal and Roth 2000; Porritt 2007). The ecocentric perspective is thus holistic, with a view toward the importance of the whole ecosystem and not its individual members or parts. As a result, it decentralizes humans as the sole locus of value, requiring a transformation of their anthropocentric beliefs about ecosystems.

\section{Paradigm Incommensurability}

In addition to these two worldviews or paradigms, multiple others could inform our research, such as technocentrism, humanism, biocentrism, or an embedded view (Dryzek 1997; Marcus et al. 2010; O'Riordan 1981; Pirson and Lawrence 2010). With the anthropocentric and ecocentric perspectives, we aim to capture two very different worldviews-a choice that is not intended to be polemic but rather to illustrate the extent of the different worldviews and establish two ends of a paradigm continuum, along which individuals and companies can position themselves (Dunlap et al. 2000). On this continuum, we can conceive of potential movement through developing (or changing) viewpoints, beliefs, values, and attitudes. In moving toward an ecocentric end of the continuum, the scope of justice expands (Du Nann Winter and Koger 2004), to encompass the needs of other species and measures other than financial ones. Measures of success for ecocentric business performance include financial (profit and cost savings), reputational, longevity, justice-based, and societal; however, all these measures of success are predicated on ecological success, which provides the life support system on which we and all other beings depend.

Karatas-Ozkan and Murphy (2010) also argue for paradigm fluidity and movement over time, cautioning that Burrell and Morgan's (1979) original concept of four mutually exclusive enclaves as paradigms (functionalist, interpretivist, radical humanist, and radical structuralist) may not be salient for researching scientific, social, and organizational phenomena, because polarizing paradigms cannot fully reflect their complexity. Similar to Patton 
(2002), they suggest a synthesis across approaches, achieved by revisiting Kuhn's (1970) thesis of scientific activity as a process of movement in which new paradigms emerge, so that the substantial continuity and overlap between paradigms can be acknowledged in research practice. Kuhn (1970) also notes the importance of scientific evolution as a succession of paradigm shifts, each of which completely reorganizes the mental models of the community of practitioners in the scientific field. For these reasons, we argue that anthropocentrism and ecocentrism are ends of a continuum, along which individuals and companies can view and continually review their changing philosophical positions. In turn, we believe theory building at the intersection of ecological sustainability and strategic management is a worthwhile exercise for expanding the strategic management field.

\section{Ecological Sustainability $\times$ Strategic Management}

Ecological sustainability derives from and is a discipline of the natural sciences; dynamic capabilities are a perspective that derives from a social sciences discipline, namely, management studies and the field of strategic management. Therefore, we must grapple with how to position our new theoretical concepts (Markóczy and Deeds 2009; Zahra and Newey 2009). Zahra and Newey (2009) advocate developing new theory at the intersection or interface of different theories, fields, or disciplines; Markóczy and Deeds (2009) support theoretical development within disciplines and fields to encourage the growth of a discipline, so that it can mature and "stand proud" next to other disciplines. In addition, Zahra and Newey (2009) explicitly support interdisciplinary research in theory development, whereas Markóczy and Deeds (2009) support it in restricted circumstances: "interdisciplinary research may be the right approach in some ground-breaking studies that address complex questions or for some meta-level studies that try to understand complex problems and phenomena, like understanding the nature of the firm, that exists in a nexus of relationship between government, individuals, markets and other social institutions." Zahra and Newey (2009) focus on a high impact contribution of theory-building research, which they refer to as a "transforming the core" category that goes beyond simply borrowing and domesticating theories from one field (Oswick et al. 2011). Instead, it borrows concepts/theories from one field and intersects them with concepts from another field in a way that extends one or more of the intersecting theories but also transforms the core of those fields and their disciplines. The outcome is a transformation of ideas in the parent domain, based on lessons learned from its extension into the focal domain. When interdisciplinary research takes this approach, it likely makes a greater impact, such that it should be more useful to practice.

Attempting to incorporate ecological sustainability thinking into management theory and practice is a complex, multifaceted exercise; we also believe it is necessary. Developing business strategies that incorporate ecological sustainability both extends intersecting theories and disciplines and also potentially transforms the core of a dominant perspective in strategic management, namely, the dynamic capabilities view (Mellahi and Sminia 2009).

The idea of integrating the principles of strategic management and ecological sustainability is not new (Hawken 1993; Tibbs 1993), but most literature does not extend far enough, philosophically or conceptually, such that it does not account for ecocentric thinking. Gladwin et al. (1995), Hart (1995), and Shrivastava (1995) started the conversation; Hart (1997) made a significant contribution by formulating a sustainability vision for business. However, Hart did not map out or formulate what a sustainability vision might look like, such that this contribution lacked analytical and predictive qualities (Markóczy and Deeds 2009). The alignment of sustainability vision thinking with base-of-pyramid (BoP) strategies (Hart 2007; London 2009) mostly addresses multinational corporation's strategies for the poorest segments of human society (Ansari et al. 2012), akin to a sustainable development strategy rather than a strategy and vision for ecological sustainability (Sharma and Lee 2012). A BoP approach excludes many firms in developed nations, emerging economies, and developing nations; it also reduces the strategic importance of the biophysical environment for the future.

Other authors contribute to ecological sustainability but without linking their ideas to business strategy types. For example, McDonough and Braungart (2002) cite the notion of eco-effectiveness and suggest that products of all kinds should be made so that they do not compromise nature's cycles or its ability to break down waste. Stead and Stead (2004, 2010) contribute a systems perspective to a manufacturing value-chain analysis, suggesting that closed-loop, cradle-to-cradle cycles should operate in an open living system economy, where industrial systems and natural systems coexist without causing damage to nature.

On the basis of this extant literature and the two philosophical perspectives of sustainability, we identify business strategies that incorporate both ecocentrism and ecological sustainability. Building on contributions from Hart (1995, 1997), Hart and Dowell (2011), McDonough and Braungart (2002), and Stead and Stead (2004, 2010), we theorize at the intersection of strategic management and strategies for ecological sustainability. With such an analysis at the intersection, we can seek to transform the core of dynamic capabilities literature. 


\section{Business Strategies and Sustainability}

In this section, we begin theorizing about ecological sustainability by proposing two strategic alternatives, transitional and transformational strategies, which offer distinct levels and approaches to ecological sustainability. To build our argument, we explicate three types of business strategies. First, traditional business strategies are not concerned with ecological sustainability. We compare these traditional approaches with transitional strategies for sustainability that embrace anthropocentric assumptions and with transformational strategies that embrace ecocentric assumptions. Second, we combine the dynamic capabilities framework with an ecocentric perspective and thereby propose an ecocentric dynamic capabilities framework that goes beyond the boundaries of the firm business ecosystem, with emphases on the importance of managerial perceptions about their firm's environment and performance (Klettner et al. 2014) and core psychological beliefs about ecological sustainability (Wright et al. 2012).

\section{Traditional Strategy}

A fundamental assumption for firms that use conventional business strategies is that the economy is a "closed circular flow in which ever-abundant resources, products, and services can, forever, flow from businesses to households without stressing the Earth's social and ecological systems" (Stead and Stead 2010, p. 491). Such strategies are not concerned with ecological sustainability; examples of firms that adopt this approach include Netto and Aldi. Traditional frameworks embedded in industrial organization economics, such as the five forces (Porter 1980) or the value-chain model (Porter 1985), emerge from such assumptions. The processes involved in applying these frameworks are linear and static (Teece 2007). For example, the process of selling a product and making a profit begins with procuring component parts and finishes with the use of the product by the end consumer, without any consideration of the disposal process or the exploitation of raw materials that make up the product. This linear process is thus a cradle-to-grave process; it also can be described as an open loop, because it does not close the circular loop of life and leaves used products as waste, from a human perspective. Nature lacks a concept of waste though, so high entropy, waste materials become a problem; because natural processes do not recognize them, they cannot break them down (Stead and Stead 2004). The firm and its business economy operate as though it were a separate, closed system, without any interaction, interrelationship, or responsibility toward society or natural ecosystems.
Transitional Strategy

Transitional business strategies reflect anthropocentric assumptions and can be readily identified in today's corporate arena, with examples such as Marks \& Spencer, Procter \& Gamble, Unilever, and Tesco. They operate in a linear, cradle-to-grave, open-loop fashion, but with the assumption that eco-efficiency should be pursued (McDonough and Braungart 2002). Unlike traditional strategies, this strategy introduces the 5Rs: reduce, reuse, repair, recycle, and regulate (see Table 1). In one respect, this positive approach encourages reductions in the use of precious commodities (e.g., metals, fuels, electricity, gas), and it also considers what should be done with waste materials, such as recycling them. However, these assumptions do not fundamentally change how firms make products or how consumers dispose of them. Most recycled products eventually end up in landfill sites or incineration plants, because recycling generally downgrades the fibers and materials to the point that ultimately they become useless for making new products.

Businesses that use transitional strategies still operate within a closed business system with very little interaction, interrelationship, or responsibility toward society or natural ecosystems. The products are still made conventionally, with little consideration for raw materials, the environment whence they come, the disposal process, or the environment to which they go (Martin and Kemper 2012). Therefore, 5R activities are add-on options to deal with the problems of waste and toxic material from products, after they have been created, sold, and used. This eco-efficiency process (McDonough and Braungart 2002) implies that firms are trying to be less bad than others operating according to the traditional mode. Businesses try to reduce their negative impact on the environment rather than eliminating it, such as by not creating toxic materials in the first place. The end result thus remains a physical environment cluttered by waste products and damaged by toxic production processes. Transitional strategies slow down the rate of damage and destruction to the environment, other species, and soil, water, and atmosphere-and thus to homes, leisure places, workplaces, and the quality of life.

Because the emphasis of this strategy is on resources and 5R activities, a transitional strategy reflects the RBV of the firm (Barney 1991; Levitas and Ndofor 2006; Lockett et al. 2008), and more specifically a natural RBV of the firm (Hart 1995). Hart (1995) argues that firms can achieve superior performance by managing their relationship with the natural environment and thereby developing valuable, rare, difficult-to-imitate, non-substitutable resources related to pollution reduction, product stewardship, and sustainable development. These 5R activities, with their focus on limiting damages, reflect an argument about whether it is 
Table 1 Transitional and transformational 5Rs

\begin{tabular}{|c|c|}
\hline Transitional 5Rs & Transformational 5Rs \\
\hline Reduce & Rethink \\
\hline $\begin{array}{l}\text { Reduce the quantity of material used in manufacturing certain } \\
\text { products, and domestically reduce the quantity/number of products } \\
\text { used }\end{array}$ & $\begin{array}{l}\text { This first stage requires completely rethinking the concept of what the } \\
\text { product is: Is a car a car, or is it a means of getting from A to B? } \\
\text { After determining the function of the product, we can think of } \\
\text { different ways to satisfy the function in an environmentally, closed- } \\
\text { loop way }\end{array}$ \\
\hline Reuse & Reinvent \\
\hline $\begin{array}{l}\text { Wherever possible, reuse materials and products so that the overall } \\
\text { volume demanded is reduced and the product is used to its fullest } \\
\text { extent }\end{array}$ & $\begin{array}{l}\text { Make way for reinvention: This creative, innovative, brainstorming } \\
\text { process identifies completely new concepts that may or may not be } \\
\text { based on existing products. Alliances and clean technology may be } \\
\text { required }\end{array}$ \\
\hline Repair & Redesign \\
\hline $\begin{array}{l}\text { Some products can be repaired and reused, rather than being disposed } \\
\text { of, thus extending their useful life and reducing demand for new } \\
\text { products }\end{array}$ & $\begin{array}{l}\text { Once new concepts have been identified, redesign needs to embrace } \\
\text { ecological requirements as its primary position so that products (and } \\
\text { services) are designed to be made from biological material or } \\
\text { technical materials only, eliminating waste and toxic residues. For } \\
\text { example, an upcycled vehicle might run on water and release no } \\
\text { dangerous residues, but instead contribute positively to the } \\
\text { environment by cleaning air or water as it runs }\end{array}$ \\
\hline Recycle & Redirect \\
\hline $\begin{array}{l}\text { If a product cannot be repaired or reused, recycling options exist, } \\
\text { whether domestically, municipally, or through a corporate } \\
\text { recollection scheme. Conventional recycling is a finite process for } \\
\text { most products, because the elements ultimately become degraded } \\
\text { beyond usefulness, leading to downcycling and disposal in a landfill } \\
\text { or incineration }\end{array}$ & $\begin{array}{l}\text { Redirect and recover affect the product at the end of its life. Redirect } \\
\text { refers to the need to have two clear channels for waste materials: one } \\
\text { where all waste materials go back into the industrial cycle so that } \\
\text { nothing is wasted and pollutants are not released to damage the } \\
\text { environment, thus creating a closed loop, and another for } \\
\text { biodegradable materials that can go back to nature without causing } \\
\text { any physical or chemical damage. These two channels need to be } \\
\text { kept separate. Sophisticated, productive, profitable channels need to } \\
\text { exist to make it a reality, so that industrial materials can be infinitely } \\
\text { cycled without loss of quality. This step also addresses the increasing } \\
\text { scarcity of some raw materials (e.g., copper) }\end{array}$ \\
\hline Regulate & Recover \\
\hline $\begin{array}{l}\text { Increasingly companies and individuals are subjected to laws, } \\
\text { restrictions, and regulation that control activities associated with } \\
\text { waste material. These restrictions are set to increase in the future }\end{array}$ & $\begin{array}{l}\text { To recover scarce (and not so scarce) elements and materials and use } \\
\text { them in new production and market opportunities, thus maintaining } \\
\text { their market value (industrial symbiosis) and again closing the loop. } \\
\text { This cycle then operates as an infinite, circular system with no end. } \\
\text { Only increases in end-user demand generate the need for virgin } \\
\text { resource extraction }\end{array}$ \\
\hline
\end{tabular}

worthwhile, from a profit perspective, to adopt an environmental strategy. Although the natural RBV embraces the idea of the natural environment, it is essentially static and designed to minimize firms' impact on the environment, then enjoy the advantages of doing so; it does not embrace the quest for no or a positive impact on the environment. As duly noted by Hart and Dowell (2011, p. 1476), this version may not be sufficient anymore:

...most firms continue to focus on incremental strategies such as eco-efficiency, pollution reduction, product stewardship, and corporate social responsibility. As important as these corporate initiatives have been, it is now clear that such incremental sustainability strategies will simply not be sufficient. Companies and management scholars are being challenged increasingly to develop breakthrough strategies that actually resolve social and environmental problems, rather than simply reducing the negative impacts associated with their current operations.

\section{Transformational Strategy}

The assumption behind transformational strategies differs: They develop from ecocentric assumptions (Purser et al. 1995). They embrace ecological sustainability, working within the constraints of natural ecosystems (Wittneben et al. 2012). The assumption is that business strategies should seek to eliminate waste and toxic chemicals from ever being created or deposited in the environment. 
Businesses seek to achieve eco-effectiveness (McDonough and Braungart 2002) by continually cycling only safe, biomaterials in the ecological system while keeping anything that nature does not recognize and cannot break down, or techno-materials, out of the ecological system and circulating them solely in the industrial system. To achieve ecoeffectiveness, a different set of $5 \mathrm{R}$ activities thus may be required: rethink, reinvent, redesign, redirect, and recover (see Table 1). Rather than closing the economic and business system off from society and nature, the aim is to open it and thereby integrate, emulate, and mimic natural cycles, which would allow materials and nutrients to pass through ecosystems. Such cycles are cradle-to-cradle and closed-loop. For example, when a leaf falls from a tree in autumn, it is broken down by worms and soil microbes, which release nutrients into the soil that become available for reuse in exactly the same form in which they were released. In spring, the nutrients may be taken up by the tree and made into new leaves. This process is a perfect closed-loop, cradle-to-cradle cycle, with no waste and no unrecognizable chemicals, which makes it sustainable: Trees only grow if enough nutrients, water, soil, and sunlight are available. Discarded nutrients get taken up and used again and again, with no waste. The assumption for businesses that opt for a transformational strategy thus is that resources are finite and limited, so to become ecoeffective, these firms must use the resources again and again, without downgrading them, discarding them, or producing toxic compounds that nature cannot process.

Moreover, a successful transformational strategy requires the organization to adopt a sustainability vision (Hart 1997; Hart and Milstein 2003). Managers need a long-term mindset, in which the planet's homeostatic balance is the most important consideration, and there is no separation between the social and the biophysical world. They must believe that nature and humans together form ecosystems, and their business organizations have roles to play in sustaining and enhancing those ecosystems. Therefore, the businesses must engage creatively with physical and human ecosystems to sustain competitive advantages for the future and achieve ecological sustainability.

Commercial benefits become apparent from such a transformational strategy, including the reduced need for and reduced cost of purchasing raw materials. The increasing costs of purchasing virgin, raw materials worldwide makes it more attractive for firms to find a position in which they do not need raw materials or at least need very limited quantities. In addition, such firms reduce their costs of disposal of waste materials, and particularly toxic waste materials, which represents an increasing expense for most firms. Another benefit stems from the positive effects on corporate image and reputation. With a transformational strategy, firms can claim genuine sustainability status for their products rather than
Fig. 1 a Traditional strategy (anthropocentric), b transitional strategy (anthropocentric) c transformational strategy, ecocentric dynamic capabilities framework and sustainability vision

greenwashing. Finally, firms can adjust their business model, from a model for selling products to one for renting products, and for such service-based firms, product return at the end of its life is an integral step. Thus, a television manufacturer would sell $10,000 \mathrm{~h}$ of viewing, rather than a television.

The emphasis of a transformational strategy thus is on operating in an open living system economy (business interacts directly with ecosystems without harming them) (Stead and Stead 2010). Sustaining and enhancing ecosystems in an eco-effective way implies a managerial mindset toward ecological sustainability and a quest for a sustainability vision that develops out of transformational strategies that encourage ecocentric leadership, innovation, collaboration, and a competitive advantage based on sustainability. This proactive environment strategy, to use Aragon-Correa and Sharma's (2003) term, is a dynamic capability: It allows the firm to refresh and renew its resource base (Ambrosini and Bowman 2009; Helfat et al. 2007; Wang and Ahmed 2007; Zahra et al. 2006).

In the next section, we provide a practical example that illustrates a move from a traditional anthropocentric approach to a transformational ecocentric approach; we also examine the 5Rs of transformational strategies using a dynamic capabilities lens and illuminate ways to enhance the dynamic capabilities framework to transform it into an ecocentric dynamic capabilities framework. That is, we borrow and extend, in an effort to transform dynamic capabilities literature (Zahra and Newey 2009). We examine the transformational strategies instantiated by one company: Ricoh UK.

\section{Ricoh UK}

Having developed our theoretical argument, we elaborate on it by reporting empirical data gathered from interviews conducted with the company's environment officer and internal and external documents that summarize companyspecific facts and figures. This illustration allows us to provide an example of transformational strategies while further developing our conceptualization of ecocentric dynamic capabilities.

In 1994, Ricoh UK changed its corporate philosophy from an anthropocentric approach to one that is more ecocentric. Figure 1 illustrates its new closed loop business approach, including uptake of a zero waste-to-landfill program, applied to remanufactured photocopiers. In 2000, this program was rolled out across the whole company and 


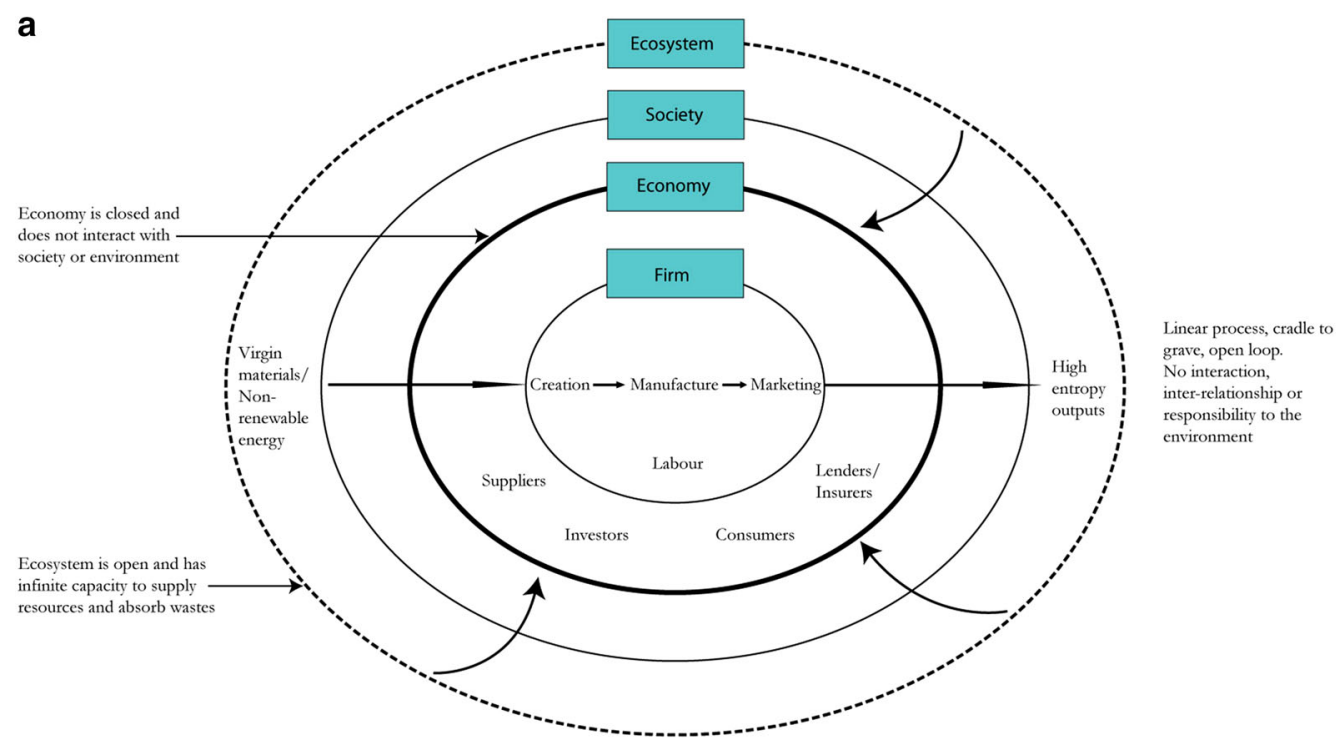

Society exploits environment for leisure and restorative activity. Take and not give back

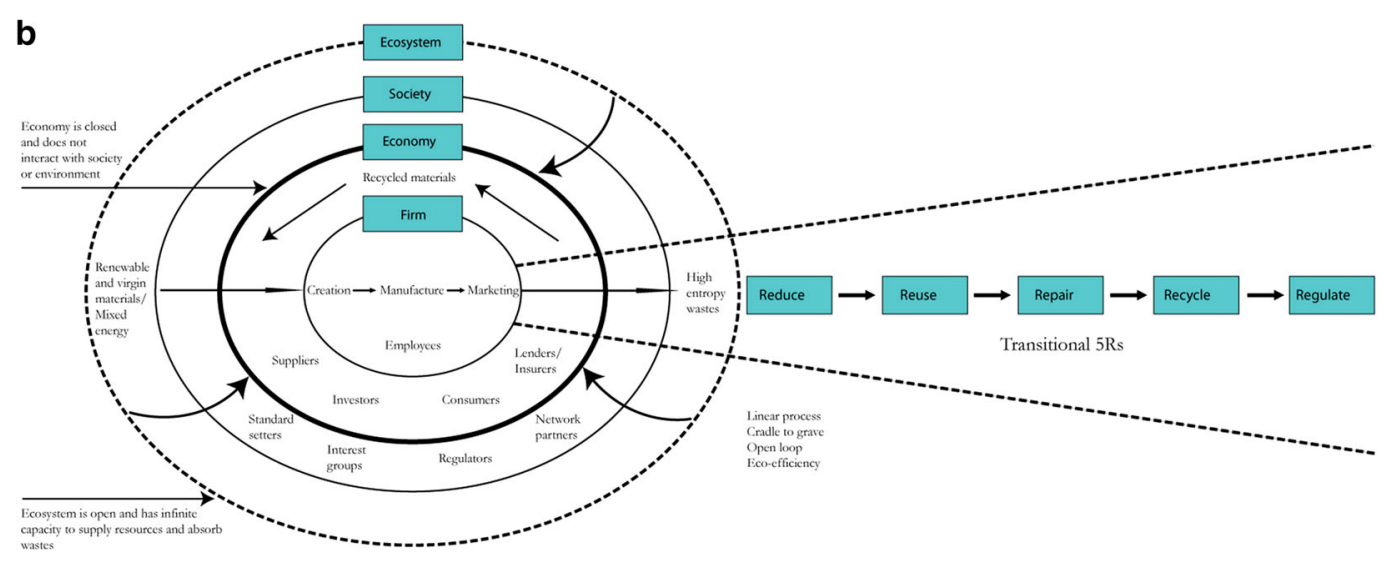

C Economy is open to (Open Living System Economy)
society and environment
through adoption of
closed loop nutrient
flows, interactions,
inter-relationships \& co-evolution

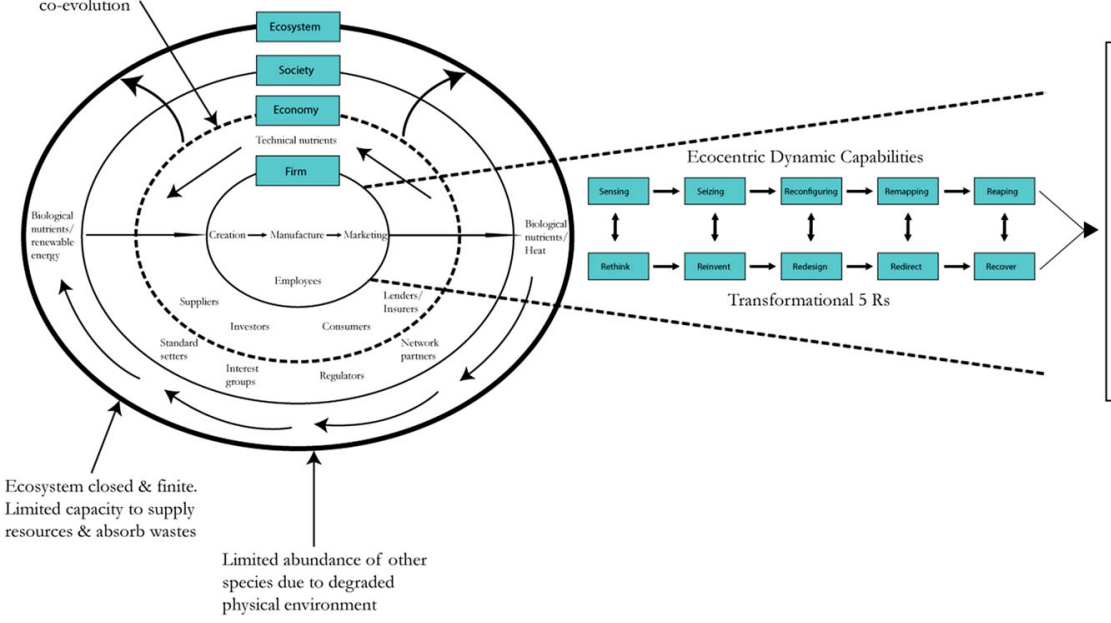
collaboration 
Fig. 2 Lifecycle: comet circle deployment. Source: Ricoh UK

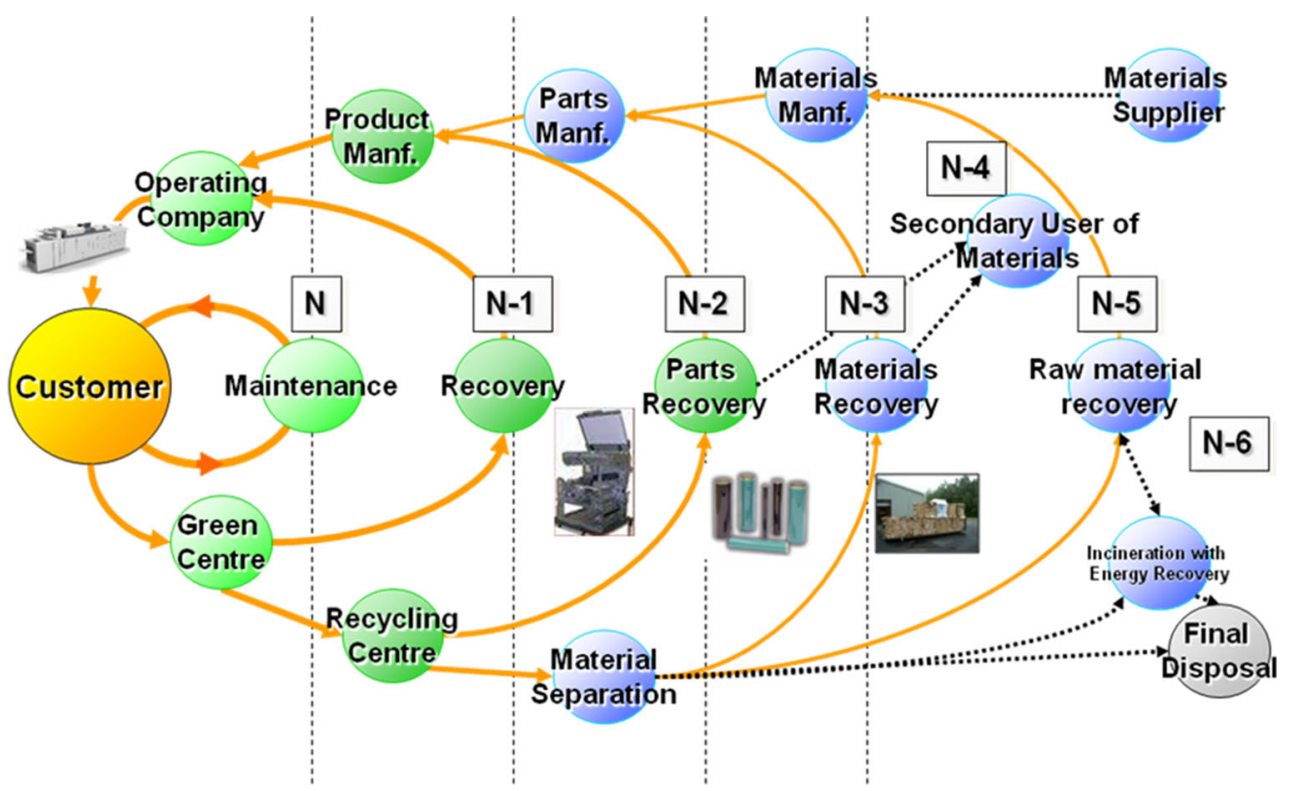

all its activities. Other streams of activity also were incorporated into this ecocentric model, including remanufacturing, harmonizing with the environment, biodiversity, and energy and carbon reduction. Although the company has not reached the far end of the continuum, it is proximate to the ecocentric end and perceives itself as on a journey toward ecocentrism. The environmental officer for Ricoh UK was responsible for leading and embedding this new program within the organization. In spearheading the program, the environmental officer made leadership and personal responsibility key themes for employees to adopt, at work and in the community (Fig. 2).

As a result, Ricoh UK has earned itself an enviable reputation among its peers and competitors for its practical application of environmental activities, including awards and accolades, a tripling of turnover, and increased profits. It also gained a position as a role model and exemplar for its industry. Furthermore, it transformed a loss-making waste stream activity into a profit-making activity $(-£ 46,000$ to $+£ 59,000$ ), because it identified and employed appropriate recycling channels for its card and plastic waste and began reusing the material without downgrading. Since 2011, $95 \%$ of its manufacturing waste is recovered and reused; only $5 \%$ undergoes incineration during remanufacturing of photocopiers (almost transformational). In terms of energy and carbon reduction - a transitional rather than transformational activity-its UK site has managed to reduce its energy bill by $£ 500,000$ annually and its carbon output by $50 \%$. Its biodiversity activities include swales of phyto-remediation plants that absorb excess rain runoff and any production spillages. These swales provide a more pleasant physical environment for staff, visitors, and wildlife; they also save the firm approximately $£ 50,000$ a year in wastewater management (transformational). Projects seek to provide homes and monitor wildlife on the site (transformational). Finally, in harmonizing with the environment, the Ricoh UK site works with educational institutions, other companies, and charitable organizations to implement environmental activities elsewhere.

In 2013, its head office in Japan announced a European reorganization, such that the manufacturing of photocopiers would move to a French site, while ink cartridge manufacturing would stay in the UK. At that point, the UK environmental officer had developed, drawn on, and exploited internal knowledge and capabilities to move Ricoh from a traditional business approach to a nearly ecocentric one. With the reorganization, he needed to adapt the knowledge, skills, and capabilities that the UK team had developed and reconfigure them to support a new business activity, in an ecocentric way, while still ensuring profits for the firm (all units must turn profits).

The first step was to determine whether ink cartridges could be remanufactured, with $95-100 \%$ recovery (transformational), which likely involves rethinking, reinventing, and redesigning the cartridges. This remapping exercise required the environmental officer to draw on previous experience and capabilities, then close the loop for producing cartridges, as well as apply previous knowledge about reducing energy and carbon emissions (or generating green energy to use in the remanufacturing process). The positive outcome for Ricoh UK would be reaping the benefits, both financial and non-financial, previously enjoyed from the remanufactured photocopiers, such that the success of the cartridges activity would become embedded into its ecocentric business model. Next, the challenge for Ricoh UK would be to rethink inks and paper 
associated with the cartridge business and examine whether they could become ecocentric (e.g., transform into biological waste and create zero toxic residues as they biodegrade, infinitely reusable paper and ink). Such efforts would once again create opportunities for ecocentric transformational strategies.

\section{Ecocentric Dynamic Capabilities}

The dynamic capabilities view is an appropriate theoretical framework for grounding business strategies for ecological sustainability (for reviews of the dynamic capabilities view, see Ambrosini and Bowman 2009; Barreto 2010). Teece (2007, pp. 1319-1320) suggests that dynamic capabilities constitute a three-stage process: "the capacity (1) to sense and shape opportunities and threats, (2) to seize opportunities, and (3) to maintain competitiveness," such that they "embrace the enterprise's capacity to shape the ecosystem it occupies." The sensing, seizing, and reconfiguring dynamic capabilities are salient for ecocentric strategies, because they explain how firms can transform themselves. We illustrate this application using the Ricoh case and reveal how three of the 5Rs-rethink, reinvent, and redesign - map onto Teece's (2007) dynamic capabilities of sensing, seizing, and reconfiguring. However, the framework as it stands may be too restrictive, because an ecosystem refers to a business ecosystem, which Teece (2007, p. 1325) defines as "the community of organizations, institutions, and individuals that impact the enterprise and the enterprise's customers and suppliers." For firms to be eco-effective and ecologically sustainable, their ecosystem, even in a dynamic capabilities framework, must extend to a global, natural ecosystem that embraces both human and biophysical worlds. Thus, we propose an ecocentric dynamic capabilities framework to help businesses become ecologically sustainable.

Taking an ecocentric view means that the manufacturing and value-chain process becomes a closed loop, which in turn demands additional steps in the dynamic capabilities framework. The dynamic capabilities also must allow for the final two steps of the 5Rs, redirect and recover. We describe these additional dynamic capabilities as remapping and reaping, as illustrated in Table 2 and with the Ricoh example.

Remapping is part of closing the loop; it requires managers to understand the difference between the biological and technical cycles of materials, the nature of the chemical make-up of those materials, and how to keep them separate. It also demands that managers find ways to rechannel waste materials "correctly" from earlier generation of produced products to reuse those materials (with the same quality as virgin materials) or dispose of them safely without chemical damage to the environment. This remapping dynamic capability extends to the capability to embed an ecocentric business model into the manufacturing of other products in the company's portfolio; as illustrated in the Ricoh example, the embedding also might involve another product line as a result of reorganization.

The reaping dynamic capability impresses on managers the notion that pursuing an ecocentric agenda need not be a sacrificial or profit-negative activity. As with any new initiative, there are implementation costs attached, but the return on investment and profit opportunities (or cost reductions) arise from both ecocentric and traditional product and process developments. If cost reduction and profit opportunities exist for both traditional and ecocentric developments, why should a manager opt for the ecocentric opportunity? At the very least, does this argument involve an appeal to the "better nature" of the managers? Yet such opportunities exist in addition to the primary profit opportunities associated with the product being sold (which, if a genuine ecocentric and sustainable product, should command a price premium). Therefore, these features constitute additional profits or cost-reducing activities, and they also provide non-financial advantages, in the form of awards, accolades, recognition, exemplar status, and helping others. As the Ricoh example shows, they bring about a new kind of competitive advantage: an ecocentric competitive advantage or competitive advantage for sustainability.

The two new dynamic capabilities of remapping and reaping, similar to sensing, seizing, and reconfiguring, highlight the importance of leaders and managers in organizations. The leadership of a company and its ability to take risk, engender trust, or create an organizational culture that embraces change is essential (Pablo et al. 2007; Rosenbloom 2000; Salvato 2003). Because of the DSP of anthropocentric assumptions, ecocentric leaders and individuals who deploy dynamic capabilities must be ecologically embedded (Whiteman and Cooper 2000). The argument that leaders and managers are critical determinants of the deployment of dynamic capabilities already is widespread in dynamic capabilities literature (Adner and Helfat 2003; Ambrosini et al. 2009; Eisenhardt and Martin 2000), as emphasized by the expression "dynamic managerial capability," which refers to "the capacity of managers to purposefully create, extend or modify the resource base of an organization" (Helfat et al. 2007, p. 24). Specifically, it is managers who must sense the environment and changes in technology, customers, suppliers, and so forth. This sensing ability, and their subsequent choice of dynamic capability deployment, depends on managers' motivation and experience (Zahra et al. 2006, 2011), their beliefs and mental models (Adner and Helfat 2003; Bruni and Verona 2009), and their willingness to change and break from old paths (Zahra et al. 2006). Using our explanation of the difference, compared with the DSP of anthropocentric logic, of ecocentric beliefs that underlie 
Table 2 Development of ecocentric dynamic capabilities

Transformational 5Rs
Rethink
This first stage requires completely rethinking the concept of what the
product is: Is a car a car, or is it a means of getting from A to B?
After determining the function of the product, we can think of
different ways to satisfy the function in an environmentally, closed-
loop way
Reinvent
Make way for reinvention: This creative, innovative, brainstorming
process identifies completely new concepts that may or may not be
based on existing products. Alliances and clean technology may be
required
Redesign
Once new concepts have been identified, redesign needs to embrace
ecological requirements as its primary position so that products (and
services) are designed to be made from biological material or
technical materials only, eliminating waste and toxic residues. For
example, an upcycled vehicle might run on water and release no
dangerous residues, but instead contribute positively to the
environment by cleaning air or water as it runs

\section{Redirect}

Redirect and recover affect the product at the end of its life. Redirect refers to the need to have two clear channels for waste materials: one where all waste materials go back into the industrial cycle so that nothing is wasted and pollutants are not released to damage the environment, thus creating a closed loop, and another for biodegradable materials that can go back to nature without causing any physical or chemical damage. These two channels need to be kept separate. Sophisticated, productive, profitable channels need to exist to make it a reality, so that industrial materials can be infinitely cycled without loss of quality. This step also addresses the increasing scarcity of some raw materials (e.g., copper)

\section{Recover}

To recover scarce (and not so scarce) elements and materials and use them in new production and market opportunities, thus maintaining their market value (industrial symbiosis) and again closing the loop. This cycle then operates as an infinite, circular system with no end. Only increases in end-user demand generate the need for virgin resource extraction
Ecocentric dynamic capabilities

\section{Sensing}

Sensing requires managers or individuals within the company to be alert to changes in the business and natural environment and to sense changing consumer demands as society, at large, becomes more sensitized to global ecological phenomena and the plight of other species

\section{Seizing}

Seizing requires managers and individuals within the company to seize new ecocentric business opportunities by brainstorming new creative and innovative processes, products, structures, and systems that can be adopted by the company and are not damaging to the physical environment. If large projects are adopted, alliances and/or clean technologies may be required

\section{Reconfiguring}

Reconfiguring requires managers, individuals, and the company as a whole to embrace the closed-loop, cradle-to-cradle requirements of ecosystems and allows for products, from their inception, to be designed and produced using only biological or technical materials; the two types of materials are kept separate at all times in the production process, during consumer use, and for return at end of life

\section{Remapping}

This new ecocentric dynamic capability embraces the ability of managers to imagine their products and processes as inputs and resources for the next generation of products, services, and processes, then find profitable, ecologically appropriate channels for these materials. This remapping will become essential as virgin resources become scarcer and more expensive, and the need to eliminate waste and pollution from the industrial system becomes a competitive necessity for continuing business activities into the future, as the financial and environmental cost of polluting increases. Remapping also refers to the ability of managers to transfer ecocentric transformational product creation strategies to other products in the company's portfolio, so an ecocentric approach becomes embedded within the company/business unit and applied to all products

\section{Reaping}

This new ecocentric dynamic capability addresses the ability of managers to benefit from the circular flow of materials, find new (profitable) channels for their waste materials, and reap the benefits in terms of financial gain (reduced costs and/or increased profits), as well as non-financial ways, such as peer group/industry recognition, accolades and awards, societal approval, improvements in reputation, or improved physical environments ecocentric dynamic capabilities, we argue that the role of cognitive framing is critical for predicting which strategies for ecological sustainability managers likely choose. Developing an ecocentric mindset represents the first step toward deploying ecocentric dynamic capabilities.

\section{Conclusions}

To conclude and complete the previous section on theory building, we suggest that intersecting the dynamic capabilities and ecological sustainability perspectives entails more than just borrowing from one field (ecological sustainability) and extending its insights to the other (dynamic capabilities) (Oswick et al. 2011). We have borrowed and applied existing principles from the dynamic capabilities view of the firm and strategies for sustainability literature, specifically its ecocentric perspective; we also have contributed to dynamic capabilities view research and the dynamic capabilities framework by extending it to include remapping and reaping, arguing that the boundaries of an enterprise are not the business environment but the 
natural environment. By acknowledging the role of managerial beliefs, we go beyond traditional anthropocentric perceptions of performance or competition to embrace a wider basket of measures that includes managers' fundamental beliefs about the relationship between humans and nature. We thus highlight that knowing how to change dynamic capabilities is a salient issue that demands further investigation. To reflect on these extensions of the framework boundaries, we propose a new concept, the ecocentric dynamic capabilities framework.

For this argument, we consider ecological sustainability literature as the parent discipline and strategy literature as the child, such that by applying ecological sustainability principles to dynamic capabilities literature, we extend the concept of dynamic capabilities. Our goal has been to contribute to strategy literature and develop a better understanding of how to integrate ecological concerns at a strategic level —an area that, despite increased public and firm concern for environmental problems, remains woefully atheoretical and academically underdeveloped (Corley and Gioia 2011). In starting to fill this gap, we hope to encourage more scholars to address this field and develop insights to help leaders and managers begin to understand, categorize, and adopt strategies that will assist them in making conscious, strategic choices that reflect their informed beliefs about ecological sustainability.

Furthermore, extending extant strategic management literature and scholarly thinking into the realm of ecocentrism and eco-effectiveness represents an interesting challenge, because existing management literature is not consistent with ecocentric thinking. We believe that to develop genuine strategies for ecological sustainability and ecocentric dynamic capabilities, it is imperative to change the way business strategies are construed. Transitional and transformational strategies are grounded in extant literature and can be generalized to theoretical and practical levels, then applied universally in first-world economies, emerging economies, developing economies, and base of the pyramid societies, as well as in firms around the world. They can be applied regardless of the size of the firm, whether it is new or incumbent, and to both product- and service-based businesses. Transformational strategies are progressive, developmental, and dynamic, as well as positive toward ecosystems, human development, and welfare. Ecocentric transformational strategies require a change in ethos, comprehension, and core values, moving toward sustainability through heightened understanding, combined with an identification with and desire to change things for the future. They are not transitional strategies, focused on incremental change created by market forces. By providing this insight into the development of business strategies for ecological sustainability, and thus a sustainability vision, we hope practitioners benefit from renewed clarity and understanding of the ways they can combine business success with ecological responsibility. Academics also have a new framework from which to observe, examine, and measure firms' business strategies for ecological sustainability (Markóczy and Deeds 2009).

On a practical level, managers and academics can use our descriptions of strategies for ecological sustainability and ecocentric dynamic capabilities to assess where an enterprise stands and how to develop a transformational strategy, should they embrace ecocentric views. They also can identify which parts of their business's value-chain operate in eco-effective or eco-efficient manners. For example, Ecover, the European manufacturer of domestic detergents, has gone a long way toward creating a transformational business. Its products, made from natural plant materials and extracts, as well as its production methods, buildings, energy consumption, and water treatment approaches are all regarded as transformational; its packaging, waste prevention, transport, and machinery use are transitional. This business thus can reexamine its value-chain activities relative to ecological sustainability and implement steps to shift its transitional activity to transformational forms. Interface, which manufactures carpeting and provides carpeting services, offers a transformational product, waste strategy, and energy use; its use of transportation is transitional (http://www.interface.co. uk). Improved ecocentric dynamic capabilities can help leaders and managers in these and other companies achieve their transformational strategy goals.

Finally, we envision theoretical research opportunities for refining and developing transitional and transformational strategies and our ecocentric dynamic capabilities framework. Empirical research should work to observe and measure business activities to distinguish between the transitional and transformational strategies that firms adopt. Research must measure both qualitative and quantitative improvements, including ecological enhancement, societal benefits, and financial uplift; qualitative research approaches may yield more informative outputs, at least in the early stages of research (Edmondson and McManus 2007), because of the interdisciplinary, integrative, systems-based nature of sustainability research, whereas quantitative research approaches may continue down a reductionist path. Testing the ecocentric dynamic capabilities framework may be challenging, because of the need to find firms willing to adopt a transformational approach. However, as the increased costs of doing business associated with resource depletion, problematic waste disposal, environmental degradation, species extinction, and devastating weather patterns become more widespread, firms willing to adopt, as well as those actively seeking, new strategic approaches likely will increase in number. 
Acknowledgments Alex Michalos served as editor for this article. Part of this article's literature review builds on Borland, H., \& Lindgreen, A. (2013).

\section{References}

Adner, R., \& Helfat, C. (2003). Corporate effects and dynamic managerial capabilities. Strategic Management Journal, 24, 1011-1025.

Ambrosini, V., \& Bowman, C. (2009). What are dynamic capabilities and are they a useful construct in strategic management? International Journal of Management Reviews, 11, 29-49.

Ambrosini, V., Bowman, C., \& Collier, N. (2009). Dynamic capabilities: An exploration of how firms renew their resource base. British Journal of Management, 20, 9-24.

Ansari, S., Munir, K., \& Gregg, T. (2012). Impact at the 'bottom of the pyramid': The role of social capital in capability development and community empowerment. Journal of Management Studies, 49, 813-842.

Aragón-Correa, J. A., \& Sharma, S. (2003). A contingent resourcebased view of proactive corporate environmental strategy. Academy of Management Review, 28, 71-88.

Augier, M., \& Teece, D. J. (2008). Strategy as evolution with design: The foundations of dynamic capabilities and the role of managers in the economic system. Organization Studies, 29, 1187-1208.

Banerjee, S. B. (2003). Who sustains whose development? Sustainable development and the reinvention of nature. Organization Studies, 24, 143-180.

Bansal, P., \& Roth, K. (2000). Why companies go green: A model of ecological responsiveness. Academy of Management Journal, 43, 717-736.

Barney, J. B. (1991). Firm resources and sustained competitive advantage. Journal of Management, 17, 99-120.

Barreto, I. (2010). Dynamic capabilities: A review of past research and an agenda for future research. Journal of Management, 36, 256-280

Belz, F. M., \& Peattie, K. (2009). Sustainability Marketing: A Global Perspective. Chichester, UK: Wiley.

Borland, H. (2009). Conceptualising global strategic sustainability and corporate transformational change. International Marketing Review, 26, 554-572.

Borland, H., \& Lindgreen, A. (2013). Sustainability, epistemology, ecocentric business and marketing strategy: Ideology, reality and vision. Journal of Business Ethics, 117, 173-187.

Bruni, D. S., \& Verona, G. (2009). Dynamic marketing capabilities in science-based firms: An exploratory investigation of the pharmaceutical industry. British Journal of Management, 20, S101-S117.

Burrell, G., \& Morgan, G. (1979). Sociological paradigms and organizational analysis. Aldershot, UK: Heinemann Educational Books.

Capra, F. (2004). The hidden connections: A science for sustainable living. New York: Anchor Books.

Castiaux, A. (2012). Developing dynamic capabilities to meet sustainable development challenges. International Journal of Innovation Management, 16, 124-140.

Corley, K. G., \& Gioia, D. A. (2011). Building theory about theory building: What constitutes a theoretical contribution? Academy of Management Review, 36, 12-32.

Dahlmann, F., \& Brammer, S. (2011). Exploring and explaining patterns of adaptation and selection in corporate environmental strategy in the USA. Organization Studies, 32, 527-553.

Diamond, J. (2006). Collapse: How Societies Choose to Fail or Succeed. London: Penguin.

Dryzek, J. (1997). The politics of the earth: Environmental discourses. Oxford: Oxford University Press.
Du Nann Winter, D., \& Koger, S. (2004). The psychology of environmental problems (2nd ed.). Englewood Cliffs, NJ: Lawrence Erlbaum Associates/Eurospan London.

Dunlap, R., Van Liere, K., Mertig, A., \& Jones, R. (2000). New trends in measuring environmental attitudes: Measuring endorsement of the new ecological paradigm: A revised NEP scale. Journal of Social Issues, 56, 425-442.

Edmondson, A. C., \& McManus, S. E. (2007). Methodological fit in management field research. Academy of Management Review, $32,1155-1179$.

Eisenhardt, K., \& Martin, J. (2000). Dynamic capabilities: What are they? Strategic Management Journal, 21, 1105-1121.

Ekins, P. (2000). Economic Growth and Environmental Sustainability. London: Routledge.

Elkington, J. (2012). The zeronauts: Breaking the sustainability barrier. London: EarthScan.

Esty, D., \& Charnovitz, S. (2012). Green rules to drive innovation. Harvard Business Review, 90, 120-123.

Gladwin, T., Kennelly, J., \& Krause, T. S. (1995). Shifting paradigms for sustainable development: Implications for management theory and research. Academy of Management Review, 20, 874-907.

González-Benito, J., \& González-Benito, O. (2005). An analysis of the relationship between environmental motivations and ISO14001 certification. British Journal of Management, 16, 133-148.

Guest, R. (2010). The economics of sustainability in the context of climate change: An overview. Journal of World Business, 45, 326-335.

Hahn, T., Pinkse, J., Preuss, L., \& Figge, F. (2014). Tensions in corporate sustainability: Towards an integrative framework. Journal of Business Ethics, (Online First).

Hart, S. (1995). A natural-resource-based view of the firm. Academy of Management Review, 20, 986-1014.

Hart, S. (1997). Beyond greening: Strategies for a sustainable world. Harvard Business Review, 75, 66-76.

Hart, S. (2007). Capitalism at the Crossroads (2nd ed.). New Jersey: Wharton School Publishing/Pearson.

Hart, S., \& Dowell, G. (2011). A natural-resource-based view of the firm: Fifteen years after. Journal of Management, 37, 1464-1479.

Hart, S., \& Milstein, M. (2003). Creating sustainable value. Academy of Management Executive, 17, 56-67.

Hawken, P. (1993). The ecology of commerce. New York: HarperCollins.

Helfat, C. E., Finkelstein, S., Mitchell, W., Peteraf, M. A., Singh, H., Teece, D. J., \& Winter, S. G. (2007). Dynamic capabilities: Understanding strategic change in organizations. London: Blackwell.

Iyer, G. (1999). Business, consumers and sustainable living in an interconnected world: A multilateral ecocentric approach. Journal of Business Ethics, 20, 273-288.

Karatas-Ozkan, M., \& Murphy, W. (2010). Critical theorist, post modernist and social constructionist paradigms in organizational analysis: A paradigmatic review of organizational learning literature. International Journal of Management Reviews, 12, 453-465.

Ketola, T. (2008). A holistic corporate responsibility model: Integrating values, discourses and actions. Journal of Business Ethics, 80(3), 419-435.

Kilbourne, W. E. (1998). Green marketing: A theoretical perspective. Journal of Marketing Management, 14, 641-655.

Klettner, A., Clarke, T., \& Boersma, M. (2014). The governance of corporate sustainability: Empirical insights into the development, leadership and implementation of responsible business strategy. Journal of Business Ethics, 122, 145-165.

Kotler, P. (2011). Reinventing marketing to manage the environmental imperative. Journal of Marketing, 75(July), 132-135.

Kuhn, T. S. (1970). The structure of scientific revolutions ( $2 \mathrm{~d}$ ed.). Chicago, IL: University of Chicago.

Levitas, E., \& Ndofor, H. A. (2006). What to do with the resourcebased view: A few suggestions for what ails the RBV that 
supporters and opponents might accept. Journal of Management Inquiry, 15, 135-144.

Lindgreen, A., \& Swaen, V. (2010). Corporate social responsibility. International Journal of Management Reviews, 12, 1-7.

Linnenluecke, M., \& Griffiths, A. (2010). Corporate sustainability and organizational culture. Journal of World Business, 45, 357-366.

Lockett, A., O'Shea, R., \& Wright, M. (2008). The development of the resource based view: Reflections from Birger Wernerfelt. Organization Studies, 29, 1125-1141.

London, T. (2009). Making better investments at the bottom of the pyramid. Harvard Business Review, May, 106-113.

Lovelock, J. (2000). The ages of Gaia: A biography of our living earth. New York: Bantam.

Marcus, J., Kurucz, E. C., \& Colbert, B. A. (2010). Conceptions of the business-society-nature interface: Implications for management scholarship. Business and Society, 49, 402-438.

Markóczy, L., \& Deeds, D. L. (2009). Theory building at the intersection: Recipe of impact or road to nowhere? Journal of Management Studies, 46, 1076-1088.

Martin, R., \& Kemper, A. (2012). Saving the planet: A tale of two strategies. Harvard Business Review, 90, 48-56.

McDonough, W., \& Braungart, M. (2002). Cradle to cradle: Remaking the way we make things. New York: North Point Press.

Mellahi, K., \& Sminia, H. (2009). Guest editors' introduction: The frontiers of strategic management research. International Journal of Management Reviews, 11, 1-7.

Metcalf, L., \& Benn, S. (2013). Leadership for sustainability: An evolution of leadership ability. Journal of Business Ethics, 112, 369-384.

Mitev, N., \& Venters, W. (2009). Reflexive evaluation of an academic-industry research collaboration: Can mode 2 management research be achieved? Journal of Management Studies, 46, 733-754.

O’Riordan, T. (1981). Environmentalism. London: Pion Books.

Orlitzky, M., Schmidt, F. L., \& Rynes, S. L. (2003). Corporate social and financial performance: A meta-analysis. Organization Studies, 24, 3403-3441.

Orr, D. (2004). Earth in mind. Washington: Island Press.

Oswick, C., Fleming, O., \& Hanlon, G. (2011). From borrowing to blending: Rethinking the processes of organizational theory building. Academy of Management Review, 36, 318-337.

Pablo, A., Reay, T., Dewald, J. R., \& Casebeer, A. L. (2007). Identifying, enabling and managing dynamic capabilities in the public sector. Journal of Management Studies, 44, 687-708.

Padelford, W., \& White, D. W. (2009). The shaping of a society's economic ethos: A longitudinal study of individual's morality of profit-making worldview. Journal of Business Ethics, 85(1), 67-75.

Patton, M. (2002). Qualitative Research and Evaluation Methods. Thousand Oaks, CA: Sage.

Pirson, M., \& Lawrence, P. (2010). Humanism in business-Towards a paradigm shift? Journal of Business Ethics, 93(4), 553-565.

Porritt, J. (2007). Capitalism as if the world matters. London: Earthscan.

Porter, M. E. (1980). Competitive strategy: Techniques for analysing industries and competitors. New York: The Free Press.

Porter, M. E. (1985). Competitive advantage: Creating and sustaining superior performance. New York: The Free Press.

Purser, R. E., Park, C., \& Montuori, A. (1995). Limits to anthropocentrism: Toward an ecocentric organization paradigm? Academy of Management Review, 20, 1053-1089.

Rolston, H. (1994). Conserving natural values. New York: Columbia University Press.

Rosenbloom, R. S. (2000). Leadership, capabilities, and technological change: The transformation of NCR in the electronic era. Strategic Management Journal, 21, 1083-1103.
Salvato, C. (2003). The role of micro-strategies in the engineering of firm evolution. Journal of Management Studies, 40, 83-108.

Schaefer, A. (2007). Contrasting institutional and performance accounts of environmental management systems: Three case studies in the UK water and sewerage industry. Journal of Management Studies, 44, 506.

Schultze, U., \& Stabell, C. (2004). Knowing what you don't know: Discourses and contradictions in knowledge management research. Journal of Management Studies, 41, 549-573.

Sharma, A., \& Lee, M. D. (2012). Sustainable global enterprise: Perspectives of Stuart Hart, Ans Kolk, Sanjay Sharma and Sandra Waddock. Journal of Management Inquiry, 21, 161-178.

Shrivastava, P. (1995). The role of corporations in achieving ecological sustainability. Academy of Management Review, 20, 936-960.

Spilhaus, A. (1972). Ecolibrium. Science, 175, 711-715.

Starik, M., \& Marcus, A. (2000). Introduction to the special research forum on the management of organizations in the natural environment: A field emerging from multiple paths, with many challenges ahead. Academy of Management Journal, 43, 539-546.

Stead, W. E., \& Stead, J. G. (2004). Sustainable Strategic Management. New York: M. E. Sharpe Inc.

Stead, J. G., \& Stead, W. E. (2010). Sustainability comes to management education and research: A story of co-evolution. Academy of Management Learning and Education, 9, 488-498.

Teece, D. (2007). Explicating dynamic capabilities: The nature and microfoundations of sustainable enterprise performance. Strategic Management Journal, 28, 1319-1350.

Teece, D. J., Pisano, G., \& Shuen, A. (1997). Dynamic capabilities and strategic management. Strategic Management Journal, 18, 509-533.

Tibbs, H. (1993). Industrial ecology: An environmental agenda for industry. Government White Paper, Washington: Global Business Network.

UN Commission on Environment and Development. (1987). The Brundtland report-'Our common future'. New York: Oxford University Press.

Wang, C., \& Ahmed, P. (2007). Dynamic capabilities: A review and research agenda. International Journal of Management Reviews, 9, 31-51.

Westley, F., \& Vredenburg, H. (1996). Sustainability and the corporation: Criteria for aligning economic practice with environmental protection. Journal of Management Inquiry, 5, 104-119.

Whiteman, G., \& Cooper, W. (2000). Ecological embeddedness. Academy of Management Journal, 43, 1265-1282.

Wittneben, B., Okereke, C., Banerjee, S. B., \& Levy, D. (2012). Climate change and the emergence of new organizational landscapes. Organization Studies, 33(11), 1431-1450.

Wright, C., Nyberg, D., \& Grant, D. (2012). "Hippies on the third floor": Climate change, narrative identity and the micro-politics of corporate environmentalism. Organization Studies, 33, 1451-1475.

Wu, Q., He, Q., Duan, Y., \& O'Regan, N. (2012). Implementing dynamic capabilities for corporate strategic change toward sustainability. Strategic Change, 21, 231-247.

Zahra, S. A., Abdelgawad, S. G., \& Tsang, E. W. K. (2011). Emerging multinationals venturing into developed economies: Implications for learning, unlearning, and entrepreneurial capability. Journal of Management Inquiry, 20, 323-330.

Zahra, S., \& Newey, L. R. (2009). Maximizing the impact of organization science: Theory building at the intersection of disciplines and/or fields. Journal of Management Studies, 46, 1059-1075.

Zahra, S., Sapienza, H., \& Davidsson, P. (2006). Entrepreneurship and dynamic capabilities: A review, model and research agenda. Journal of Management Studies, 43, 917-955. 